\title{
Overnight Cost Estimation of Indonesia's Cogeneration Power Plant for Industrial Processes
}

\author{
${ }^{1}$ Rizki Firmansyah Setya Budi*, ${ }^{2}$ Rr. Arum Puni Rijanti, ${ }^{2}$ Sahala M. Lumbanraja, ${ }^{2}$ Elok S. Amitayani, ${ }^{2}$ Moch. \\ Djoko Birmano, ${ }^{2}$ Edwaren Liun \\ ${ }^{1}$ Electrical Engineering, Gadjah Mada University, Bulak Sumur, Yogyakarta \\ ${ }^{2}$ Center for Assessment of Nuclear Energy System - National Nuclear Energy Agency of Indonesia, Jl. Kuningan Barat Mampang \\ Prapatan, Jakarta Selatan 12710, Indonesia
}

\begin{tabular}{l}
\hline ARTICLE INFORMATION \\
\hline Article History: \\
Received: \\
03 December 2018 \\
Received in revised form: \\
25 January 2019 \\
Approved: \\
28 January 2019 \\
\end{tabular}

\section{Keywords:}

PeLUIt

Estimasi

Reaktor berpendingin gas suhu

tinggi

Biaya sesaat

Scaling law

\begin{abstract}
ABSTRAK
ESTIMASI BIAYA SESAAT PEMBANGKIT COGENERASI INDONESIA UNTUK PROSES INDUSTRI. Pembangkit listrik kogenerasi untuk proses industri (PeLUlt) diperlukan untuk diterapkan di Indonesia. Analisis ekonomi merupakan faktor penting untuk implementasi PeLUlt. Salah satu data yang perlu dalam analisis adalah biaya sesaat. Penelitian ini memperkirakan biaya sesaat HTGR menggunakan scaling law. Dengan menggunakan nilai estimasi, dapat dihitung biaya sesaat PELUIt. Tujuan penelitian adalah untuk mendapatkan perkiraan biaya sesaat dari PeLUIt. Hasil estimasi menunjukkan biaya sesaat PeLUIt. PeLUIt 10 MWth memiliki biaya sesaat 166,26 juta USD. PeLUIt 30 MWth memiliki biaya sesaat 233,49 juta USD. PeLUIt 50 MWth memiliki biaya sesaat 281,31 juta USD. PeLUIt 100 MWth memiliki biaya sesaat 371,86 juta USD. PeLUIt 350 MWth memiliki biaya sesaat 657,16 juta USD.
\end{abstract}

\begin{abstract}
OVERNIGHT COST ESTIMATION OF INDONESIA'S COGENERATION POWER PLANT FOR INDUSTRIAL PROCESSES. Indonesia's cogeneration power plant for industrial processes (PeLUIt) is needed to be implemented in Indonesia. Economic analysis is an important factor for PeLUIt implementation. One of the data that needs in the analysis is overnight cost. This research estimates HTGR's overnight cost using scaling law. By using the estimated value, it can be calculated the PeLUIt overnight cost. The research's purpose is to obtain an estimation of overnight costs of PeLUIt. The estimation result shows the overnight cost of PeLUIt. PeLUIt 10 MWth has an overnight cost 166,26 million USD. PeLUIt 30 MWth has an overnight cost 233,49 million USD. PeLUIt 50 MWth has an overnight cost 281,31 million USD. PeLUIt 100 MWth has an overnight cost 371,86 million USD. PeLUlt 350 MWth has an overnight cost 657,16 million USD.

Keywords: PeLUIt; estimation; high temperature gas-cooled reactor; overnight cost; scaling law
\end{abstract}

(c) 2018 Jurnal Pengembangan Energi Nuklir. All rights reserved

\section{PENDAHULUAN}

One of the objectives of the National Industrial Development Master Plan (RIPIN) 2015-2035 is Indonesia become a strong industrial country. It is necessary to build an industrial areas to achieve the objective[1]. The development of the industrial areas highly depend on the availability and quality of electrical energy. On the other hand, not all of the areas have a good supply and quality of electrical energy, So it needs an effort to increase the supply and quality of electrical energy in the region. Increased supply and quality can be done by using captive power[1].

${ }^{*}$ Correspondence author.

E-mail: rizkifirmansyah@batan.go.id
The areas are located close to the location of gas pipelines, refineries, and ports. Therefore, it is expected that the captive power to be built not only to generate electricity, but also to generate heat/thermal energy. The electrical energy is used to meet the electricity needs of industrial areas, while the thermal energy can be used for industrial hot steam applications such as desalination, hydrogen production, coal gasification, coal liquefaction, enhance oil recovery and coal drying [2]-[7].

High Temperature Gas-cooled Reactor (HTGR) is a type of reactor that can be used for industrial electricity and heat generation (cogeneration process)[8], [9]. Heat from 
HTGR can be used for the heat process of chemical industry, steel, oil refinery, oil mine, hydrogen, coal gasification, coal liquefaction, coal drainage and desalination [10]-[17]. Based on this fact, HTGR has the potential to be used as a captive power in industrial areas in Indonesia. However, currently there is no HTGR that operate commercially, so the cost of overnight cost of HTGR cannot be determined surely [18]-[25].

National Nuclear Agency of Indonesia (BATAN) has planned to build experimental power reactor (RDE). RDE will use HTGR technology with capacity of $10 \mathrm{MWth}(3 \mathrm{MWe})$. In addition to produce electricity and heat, RDE will also be used as an experimental heat process application reactor in order to master the concept of cogeneration process [26]. RDE is also expected to become a pilot project of Indonesia's cogeneration power plant for industrial processes (PeLUIt). PeLUIt is planned to have capacity ranging from 3 to 100 MWe (10 MWth to 350 MWth). Based on its capacity and usefulness, PeLUIt is well suited to be used as captive power in industrial area and can support the objective of RIPIN.

The absence of HTGR overnight cost complicates the implementation of HTGR as a captive power in industrial areas. Estimation of HTGR overnight cost is needed to conduct economic analysis in order to know the level of economic feasibility of PeLUIt as a captive power in industrial area. Therefore, we need a study that makes estimation of overnight cost of PeLUIt. On the other hand, the current stage of RDE development is perfecting the detail design. Therefore, it is needed an overnight cost estimation of RDE 10 MWth (PeLUIt pilot project). The estimation can be used as a reference in the design improvement.

Idaho National Laboratory has estimated cost of overnight cost of Next Generation Nuclear Plant (NGNP)- HTGR of 600 MWth $750^{\circ} \mathrm{C}$ and 350 MWth $750^{\circ} \mathrm{C}$. NGNP HTGR current status is in research and development phase. Using the NGNP data, Idaho adjusted overnight costs to look for overnight costs of HTGR with different capacities [27]. In addition to the adjusted overnight cost method used by Idaho, the cost of overnight cost for different capacities can be done by using scaling law[28].
The research [28] and [29] used scaling law to obtain investment costs on large-scale nuclear power plants and SMR PWR. The research in[24] estimated the cost of modular HTR investment based on investment cost of HTR PM on preliminary design. The method used to analyze the components that can be saved by the modularization. Nevertheless, the research was not mentioned in detail the investment cost of HTR-PM.

The result of the research shows the relationship between cost function and capacity. The research [30], [31] have used scaling law methods in the pharmaceutical and chemical industries. The purpose of the use of scaling law is to reduce the cost of the experimental process while maintaining the characteristics on a large scale, so that the results of the experiment can be used for the commercialization stage.

This research will estimate the overnight cost of PeLUIt. The method used to make estimation is scaling law. It is expected that with this research, it will get the estimation ofPeLUIt overnight cost. It is expected that by using overnight cost estimation of PeLUIt, economic analysis of PeLUit can be performed. In addition, the overnight cost of PeLUIt 10 MWth can be used as a refference for RDE detail design improvement.

\section{METHODS}

This research is conducted by using flowchart shown in Figure 1. The study begins with the literature review to obtain data on HTGR overnight cost and methods that can be used to estimate HTGR overnight cost. Based on the literature review results a hypothesis that scaling law can be used to estimate overnight cost of HTGR with various capacities. After obtaining the overnight cost component of HTGR, overnight cost of NGNP HTGR, and scaling law method, the scaling down process of NGNP HTGR to get the HTGR overnight cost with the desired capacity can be done. The next step after getting the estimation is the validity test. Validity test is done by comparing the estimation result of scaling factor method with estimation from Idaho.After the HTGR cost is validated, PeLUIt overnight 
cost estimation can be done based on HTGR cost with some adjustments.

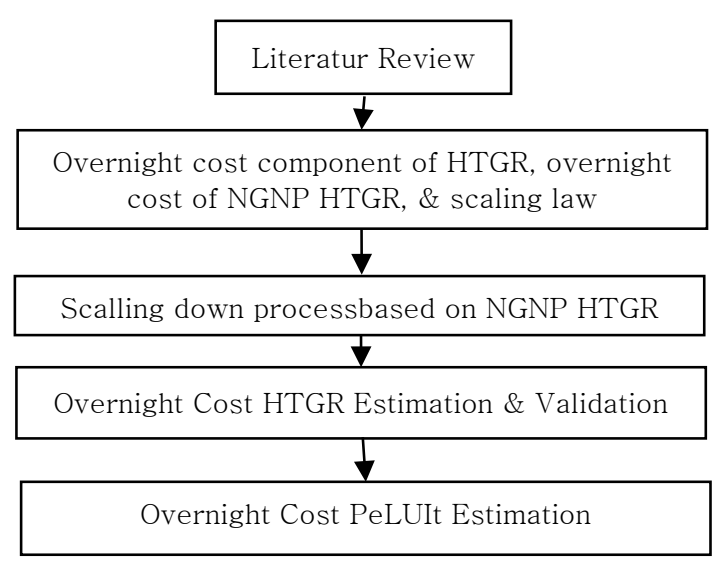

Figure 1. Research Process Flowchart.

\subsection{Overnight Cost Components of HTGR}

HTGR overnight cost consists of 3 main components, namely: pre-construction cost, direct cost, and indirect cost. Pre-construction costs consist of land \& land rights cost, and licensing \& application costs. Licensing cost covers the cost of certification design as well.

Table 1 shows the pre-construction cost of NGNP HTGR. Table 2 shows direct costs of the HTGR. Table 3 shows indirect costs of the HTGR.

Table 1. NGNP HTGR Pre-construction Costs

\begin{tabular}{lcc} 
& $\left(10^{6}\right.$ USD) [27] & \\
\hline & $\begin{array}{c}\text { 600 MWth } \\
\text { (ROT 750) }\end{array}$ & $\begin{array}{c}\text { 350 MWth } \\
\text { (ROT 750) }\end{array}$ \\
\hline $\begin{array}{l}\text { Land and Land } \\
\text { Rights }\end{array}$ & 5 & 5 \\
$\begin{array}{l}\text { Licensing and } \\
\text { Application Costs }\end{array}$ & 228.5 & 228.5 \\
\hline
\end{tabular}

Table 2. NGNP HTGR Direct Costs (10 USD) [27]

\begin{tabular}{lcc}
\hline & 600 & 350 \\
& MWth & MWth \\
\hline Reactor Building & 214.30 & 163.67 \\
Reactor Vessel & 133.65 & 92.31 \\
Reactor Initial Core & 133.11 & 86.13 \\
Reactor Metallic Internals & 37.66 & 35.89 \\
Reactor Graphite Internals & 28.05 & 28.05 \\
Reactor Cavity Cooling System & 30.75 & 23.49 \\
Core Refueling Equipment & 98.04 & 73.53 \\
Heat Rejection System & 44.70 & 34.14 \\
IHX & 31.09 & 21.97 \\
Power Generation-Rankine & & \\
$\quad$ Cycle & 170.79 & 130.44 \\
BOE-Rankine Power Cycle & 230.54 & 172.40 \\
\hline
\end{tabular}

Table 3. NGNP HTGR Indirect Costs (106 USD) [27]

\begin{tabular}{lcc}
\hline & 600 & 350 \\
& MWth & MWth \\
\hline $\begin{array}{l}\text { Const. Services } \\
\text { Home Office \& Eng. }\end{array}$ & 230.54 & 172.40 \\
$\quad$ Services & 184.43 & 137.92 \\
Field Office \& Eng. & & \\
$\quad$ Services & 115.27 & 86.20 \\
Owner + HRD & 138.32 & 103.44 \\
\hline
\end{tabular}

\subsection{Scaling Law and Overnight Cost Estimation from Idaho}

Scaling law is a method used to estimate the cost of overnight cost at a certain size based on the existing cost at a certain capacity [28]-[32]. Scaling law is done by using equation 1 , where $\mathrm{n}$ is the scaling factor value. Determination of scaling factor value is determined by several things such as design simplification, size, and component adjustment.

$$
\text { New Cost }=\text { Known Cost } \times\left[\frac{\text { NewCapacity }}{\text { KnownCapacity }}\right]^{\mathrm{n}}
$$

While in the study [27], the overnight cost estimation uses the equations obtained based on data and experiences that have been owned by Idaho. Equations 2 and 3 are used to calculate the direct cost components that are unrelated to the generation of electrical energy and the Barrel Oil Equivalent (BOE).

Cost $=0.258 \times 750+250.952$

$$
\begin{aligned}
& \text { Adjusted Cost }=1.758 \times \text { Cost } \times \\
& 1^{0.827} \times\left[\frac{\text { NewThermalCapacity }}{600 \text { MWth }}\right]^{0.673}
\end{aligned}
$$

For components related to electricity generation (Rankine cycle cost) and $\mathrm{BOE}$ equations 4 and 5 are used.

Adjusted Rankine Cycle Cost $=1.429 \times$

$(0.236 \times 750-58.775) \times\left[\frac{\text { NewCapacity }}{267 \text { MWe }}\right]^{0.5}$

Adjusted BOE Cost $=0.25 \times$

Total direct cost without $\mathrm{BOE}$

For indirect cost components, Idaho calculates using equations 6 to 9 .

Const. Services $=0.2 \times$ direct costs 
Home Office \& Eng. Services $=$ $0.16 \times$ direct costs

Field Office \& Eng. Services $=$ $0.10 \times$ direct costs

Owner $+H R D=0.12 \times$ direct costs

Based on the Association for the Advancement of Cost Engineering (AACE), the type of estimation by using scaling law and Idaho calculation is included in AACE International Class 4 estimation which has an error between $-30 \%$ to $+50 \%$. Class 4 estimation can be used for feasibility study[27], [33]. This research uses Class 4 estimationbecause the purpose of this research is to obtain an overnight cost that can be used for economic analysis of the implementation of HTGR in the industrial area.

\subsection{Validity Test}

Validity test is done by doing comparison of estimation result between scaling law with the Idaho calculation. From the comparison results, it will be obtained percentage of estimation error value using scaling law. The percentage error value is calculated using equation 10 . If the error value is in the range between $-30 \%$ to $+50 \%$ then the estimation using scaling law is declared valid.

Error $=\left[\frac{\text { Estimasiscalinglaw }- \text { Estimasildaho }}{\text { Estimasiscalinglaw }}\right] \times 100 \%$

\subsection{PeLUIt Overnight Estimation}

RDE overnight cost estimation were performed by using validated HTGR estimation which adjusted to the specification of PeLUIt. PeLUIt have reactor outlet temperature (ROT) $530^{\circ} \mathrm{C}$ and classified as NOAK technology.

The NGNP from Idaho is classified as experimental technology. Therefore, it need to convert the validated HTGR cost to NOAK cost. Based on Idaho data, the adjustment for direct and indirect cost from experimental to NOAK is done by using equation 11 . While for preconstruction cost is 76.5 million USD for NOAK[27].

$$
\begin{gathered}
\text { Direct } N O A K=0,5688 \times \text { direct } \\
\text { and }
\end{gathered}
$$$$
\text { Indirect NOAK }=0,5688 \mathrm{x} \text { indirect }
$$

NGNP has intermediate heat exchanger (IHX) with ROT $750^{\circ} \mathrm{C}$, while PeLUIt are designed without IHX with ROT $530^{\circ} \mathrm{C}$. Therefore, adjustments on validated HTGR costs are needed to make PeLUIt overnight cost estimation. The adjustments are done by removing the IHX and decreasing its ROT value. The adjustment on the ROT is done by using equation 12 .

$$
\text { New Cost }=\text { Known Cost } \times\left[\frac{\text { NewROT }}{\text { KnownROT }}\right]^{n}
$$

The value of $n$ is calculated using data in Table 4. The calculation of $\mathrm{n}$ only used total direct cost for two reasons. The preconstruction cost had same value for each ROT. The indirect cost was the function of direct cost (based on equation 6-9) so that the changes followed the direct cost changing.

Table 4. NGNP HTGR Direct Costs with various ROT $\left(10^{6}\right.$ USD) (INL, 2012)

\begin{tabular}{lrrr|rrr}
\hline & \multicolumn{3}{c}{ 600 MWth } & \multicolumn{3}{c}{ 350 MWth } \\
\hline & ROT & ROT & ROT & ROT & ROT & ROT \\
& 750 & 800 & 850 & 750 & 800 & 850 \\
\hline $\begin{array}{c}\text { Total direct } \\
\text { cost }\end{array}$ & 704,83 & 733,34 & 764,15 & 500,14 & 520,93 & 543,4 \\
\hline
\end{tabular}

\section{RESULTS AND DISCUSSION}

Based on data in Table 1, Table 2, and Table 3 it can get the scaling factor value of each component of overnight cost HTGR NGNP.

Table 5 shows the scaling factor values for each component of HTGR NGNP. The scaling factor value is obtained by entering data of Table 1, Table 2 and Table 3 into equation 1. The scaling factor value influences the changing rate of cost caused by the change of capacity. The greatervalue of scaling factor, the greater price change due to capacity changes. 
Table 5. Scaling factor of each component of NGNP HTGR $\left(10^{6} \mathrm{USD}\right)$

\begin{tabular}{|c|c|c|c|}
\hline & $\begin{array}{r}600 \text { MWth } \\
750^{\circ} \mathrm{C} \\
\end{array}$ & $\begin{array}{r}350 \\
\text { MWth } \\
750^{\circ} \mathrm{C} \\
\end{array}$ & $\begin{array}{l}\text { Scaling } \\
\text { Factor }\end{array}$ \\
\hline $\begin{array}{l}\text { Pre-construction costs } \\
\text { Land and Land Rights } \\
\text { Licensing and }\end{array}$ & 5 & 5 & 0 \\
\hline Application & 228.5 & 228.5 & 0 \\
\hline Direct cost & & & \\
\hline Reactor Building & 214.3 & 163.67 & 0.5 \\
\hline Reactor Vessel & 133.65 & 92.31 & 0.69 \\
\hline $\begin{array}{l}\text { Reactor Initial Core } \\
\text { Reactor Metallic }\end{array}$ & 133.11 & 86.13 & 0.81 \\
\hline $\begin{array}{l}\text { Internals } \\
\text { Reactor Graphite }\end{array}$ & 37.66 & 35.89 & 0.09 \\
\hline $\begin{array}{l}\text { Internals } \\
\text { Reactor Cavity Cooling }\end{array}$ & 28.05 & 28.05 & 0 \\
\hline $\begin{array}{l}\text { System } \\
\text { Core Refueling }\end{array}$ & 30.75 & 23.49 & 0.5 \\
\hline Equipment & 98.04 & 73.53 & 0.53 \\
\hline Heat Rejection System & 44.7 & 34.14 & 0.5 \\
\hline IHX & 31.09 & 21.97 & 0.64 \\
\hline $\begin{array}{l}\text { Rankine Cycle } \\
\text { BOE-Rankine Power }\end{array}$ & 170.79 & 130.44 & 0.5 \\
\hline Cycle & 230.54 & 172.4 & 0.54 \\
\hline Indirect Cost & 230.54 & 172.40 & 0.54 \\
\hline $\begin{array}{l}\text { Home Office \& Eng. } \\
\text { Services } \\
\text { Field Office \& Eng. }\end{array}$ & 184.43 & 137.92 & 0.54 \\
\hline $\begin{array}{l}\text { Field Office \& Eng. } \\
\text { Services }\end{array}$ & 115.27 & 86.20 & 0.54 \\
\hline Owner + HRD & 138.32 & 103.44 & 0.54 \\
\hline
\end{tabular}

Price components that are not affected by capacity change are pre-construction costs components and graphite internals reactor with zero scaling factor. This indicates that capacity changes have no effect on prices on the components of pre-construction costs and reactor graphite internals. Pre-construction costs do not change when size is changed. This is because size changes do not cause significant changes in land cost and licensing costs. Pre-construction costs will change as the number of reactors changes, e.g. for 600 MWth capacity using 1 reactor and 600 MWth capacity using 2 reactors having different preconstruction costs. Reactor graphite internals have the same typeas pre-construction costs. Capacity changes do not cause significant changes in the graphite internals reactor.

The components most affected by capacity change are the initial core reactor with the scaling factor value of 0.89 , the reactor vessel with the scaling factor value of 0.65 , and the IHX with the scaling factor value of 0.64. Larger capacity requires larger initial core that will lead to significant price increases. Increased capacity requires stronger vessel reactor so that the price increases significantly. Increased capacity requires larger IHX which causes the price to increase significantly.

Based on the scaling factor in Table 5, cost estimation from each component of HTGR overnight cost can be acquired. The cost estimation is shown in Table 6. Each component of the cost changes based on its scaling factor value. Overnight cost of HTGR NGNP varies depending on its capacity. HTGR 600 MWth has an overnight cost of 2054.73 million USD, HTGR 350 MWth has an overnight cost of 1595.49 million USD, HTGR 100 MWth has an overnight cost of 941.28 million USD, HTGR 50 MWth has an overnight cost of 734.18 million USD, HTGR 30 MWth has an overnight cost of 625 million USD, and HTGR 10 MWth has an overnight cost of 471,86 million USD.

Table 6. Overnight Costs Estimation of HTGR NGNP

\begin{tabular}{|c|c|c|c|c|c|c|}
\hline & 600 & 350 & 100 & 50 & 30 & 10 \\
\hline \multicolumn{7}{|c|}{ Pre-construction cost } \\
\hline \multicolumn{7}{|c|}{ Land and Land } \\
\hline Rights & 5.00 & 5.00 & 5.00 & 5.00 & 5,00 & 5.00 \\
\hline \multicolumn{7}{|l|}{ Licensing and } \\
\hline \multicolumn{7}{|l|}{ Application } \\
\hline Costs & 228.50 & 228.50 & 228.50 & 228.50 & 228.50 & 228.50 \\
\hline \multicolumn{7}{|l|}{ Direct cost } \\
\hline Reactor Vessel & 133.65 & 92.31 & 38.89 & 24.11 & 16.95 & 7.94 \\
\hline \multicolumn{7}{|l|}{ Reactor Initial } \\
\hline Core & 133.11 & 86.13 & 31.22 & 17.81 & 11.77 & 4.84 \\
\hline \multicolumn{7}{|l|}{ Reactor } \\
\hline $\begin{array}{l}\text { Metallic } \\
\text { Internals }\end{array}$ & 37.66 & 35.89 & 32.06 & 30.12 & 28.77 & 26.06 \\
\hline \multicolumn{7}{|l|}{ Reactor } \\
\hline $\begin{array}{l}\text { Graphite } \\
\text { Internals }\end{array}$ & 28.05 & 28.05 & 28.05 & 28.05 & 28.05 & 28.05 \\
\hline \multicolumn{7}{|l|}{ Reactor Cavity } \\
\hline Cooling & & & & & & \\
\hline System & 30.75 & 23.49 & 12.56 & 8.88 & 6.88 & 3.97 \\
\hline \multicolumn{7}{|l|}{ Core Refuelling } \\
\hline Equipment & 98.04 & 73.53 & 37.85 & 26.22 & 20.00 & 11.17 \\
\hline \multicolumn{7}{|l|}{ Heat Rejection } \\
\hline System & 44.70 & 34.14 & 18.25 & 12.90 & 10.00 & 5.77 \\
\hline IHX & 31.09 & 21.97 & 9.85 & 6.32 & 4.56 & 2.26 \\
\hline \multicolumn{7}{|l|}{ Power } \\
\hline \multicolumn{7}{|l|}{ Generation- } \\
\hline \multicolumn{7}{|l|}{ Rankine } \\
\hline Cycle & 170.79 & 130.44 & 69.72 & 49.30 & 38.19 & 22.05 \\
\hline \multicolumn{7}{|l|}{ BOE-Rankine } \\
\hline Power Cycle & 230.54 & 172.40 & 87.65 & 60.28 & 45.75 & 25.28 \\
\hline \multicolumn{7}{|l|}{ Indirect cost } \\
\hline Const. Services & 230.54 & 172.40 & 87.65 & 60.28 & 45.75 & 25.28 \\
\hline \multicolumn{7}{|c|}{ Home Office \& } \\
\hline Eng. & & & & & & \\
\hline Services & 184.43 & 137.92 & 70.12 & 48.23 & 36.60 & 20.22 \\
\hline \multicolumn{7}{|l|}{ Field Office \& } \\
\hline Eng. & & & & & & \\
\hline Services & 115.27 & 86.20 & 43.82 & 30.14 & 22.88 & 12.64 \\
\hline Owner + HRD & 138.32 & 103.44 & 52.59 & 36.17 & 27.45 & 15.17 \\
\hline \multicolumn{7}{|l|}{ Total Overnight } \\
\hline Cost & 2054.73 & 1595.49 & 941.28 & 734.18 & 625.00 & 471.86 \\
\hline
\end{tabular}


The estimation result is compared with Idaho calculation results using equation 2 to 9. Comparison is done on 3 main sub-components (pre-construction cost, direct cost, and indirect cost) and overnight cost. Figure 2shows comparison of estimation results with scaling method and Idaho calculation. Based on Figure 2 , it can be seen that the estimation result using the scaling factor is similar to Idaho estimation result. The difference in estimation results increases with reduced capacity.

Table 7 shows the difference in estimates between the scaling factor and Idaho calculations. On the main component of overnight cost, the largest difference occurs in the direct cost component of 10 MWth HTGR with a value of $45.9 \%$. Meanwhile, in the overnight cost, the biggest difference occurs on HTGR 10 MWth with a value of $20.6 \%$. If the calculation of Idaho is made as a standard, then the difference is still smaller than the possible error in the type of estimation used in this study $(-30 \%$ and $+50 \%)$. In other words, the 4 th grade estimation results used in this study can be declared valid.
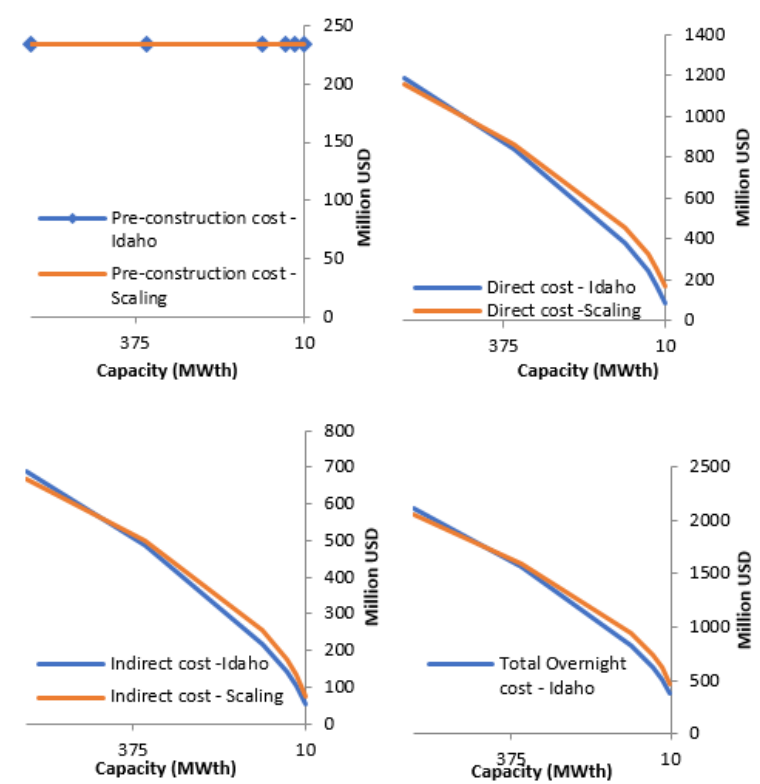

Figure 2. Comparison of Scaling Law Estimate Results with Idaho.

Table 7. Difference between Scaling and Idaho estimates

\begin{tabular}{lrrrrrr}
\hline & 600 & 350 & 100 & 50 & 30 & 10 \\
\hline Pre-construction & & & & & & \\
$\quad$ cost & $0 \%$ & $0 \%$ & $0 \%$ & $0 \%$ & $0 \%$ & $0 \%$ \\
$\begin{array}{l}\text { Direct cost } \\
\text { Indirect cost }\end{array}$ & $3.1 \%$ & $-2.5 \%$ & $-16.5 \%$ & $-25 \%$ & $-31.5 \%$ & $-45.9 \%$ \\
$\begin{array}{l}\text { Total Overnight } \\
\quad \text { cost }\end{array}$ & $2.1 \%$ & $-2.5 \%$ & $-13.6 \%$ & $-18.9 \%$ & $-22.5 \%$ & $-29.3 \%$ \\
\hline
\end{tabular}

Table 6 shown the composition ratio of composition ratio of pre-construction cost, direct cost, and indirect cost in overnight cost on each capacity of HTGR. The comparison is shown in Figure 2. At a larger capacity the direct cost component is the component that has the largest portion. This is because the costs directly related to the construction of the power plant. For small capacity, the component of pre-construction cost is the component have the biggest portion. This is because the preconstruction cost has a fixed amount even though the generating capacity is smaller. The greatest component in pre-construction cost is the licensing and application cost where this cost has a fixed amount for various generator sizes.

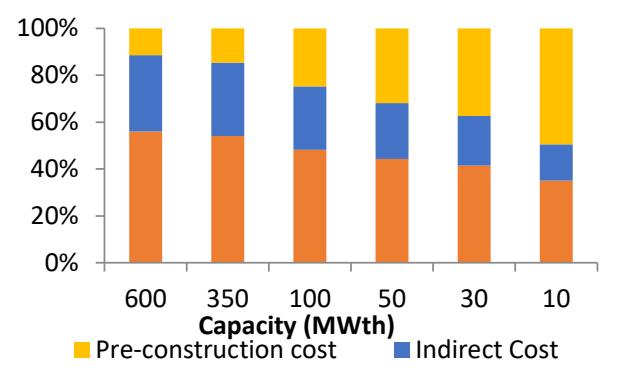

Figure 3. Composition of each cost component in Overnight Cost.

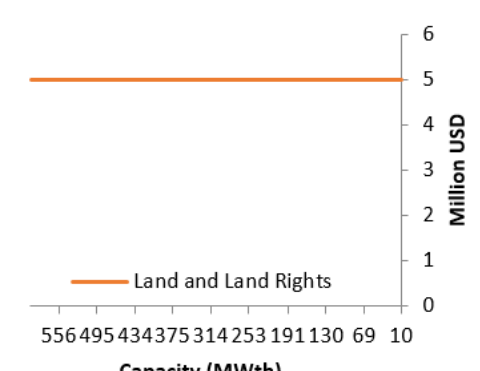

Capacity (MWth)

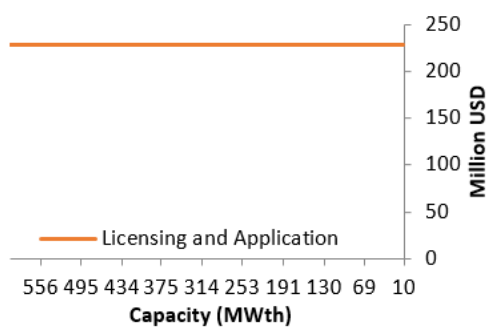

Figure 4. Estimated Pre-construction Cost of various HTGR Capacities.

The cost of overnight cost for other HTGR capacity can be obtained by making the price curve of the data in Table 6. Figure 4 shows the pre-construction cost estimation for various capacity of HTGR using scaling factor method. 

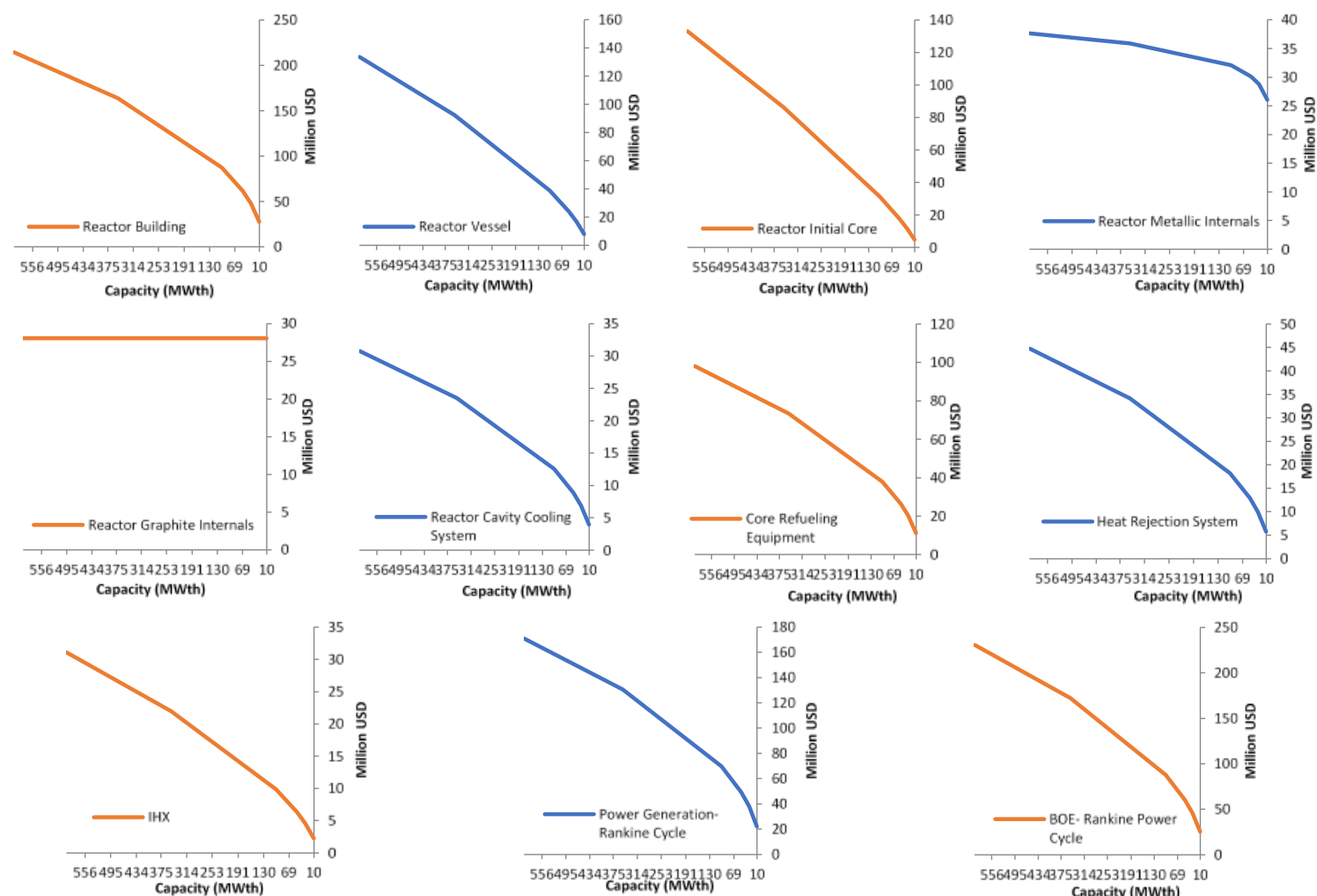
Capacity (MWth)
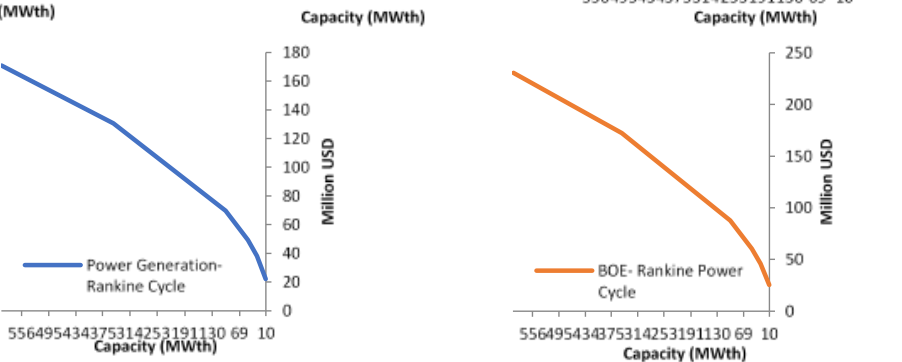

Figure 5. Direct Cost Estimate for Various HTGR Capacity.
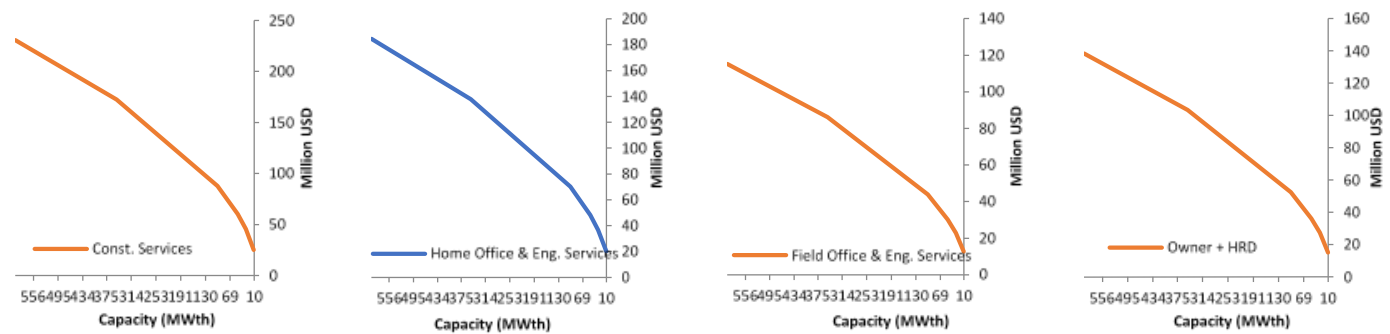

Figure 6. Indirect Cost Estimate for Various HTGR Capacity.

Figure 5 shows the direct cost estimation for various capacity of HTGR NGNP using scaling factor. Figure 6 shows the indirect cost estimation for various HTGR capacities using scaling factor. Using the estimation, it can be obtained overnight cost for HTGR which will be developed in Indonesia.

Based on the HTGR estimation, it can be estimated the PeLUIt overnight cost. Estimations are done by eliminating the IHX cost, adjusting the NGNP to NOAK, and adjusting the ROT. The adjustment of indirect and direct NGNP cost to NOAK is done by using equation 11 . The adjustment results are shown in Table 8.
Table 8. The adjustment of NGNPto NOAK(without IHX) (10 $0^{6}$ USD)

\begin{tabular}{lrrrrrr}
\hline HTGR NOAK & 600 & 350 & 100 & 50 & 30 & 10 \\
\hline $\begin{array}{l}\text { Indirect and } \\
\text { direct cost }\end{array}$ & 1004,9 & 752,8 & 392,8 & 278,5 & 218,1 & 133,3 \\
\hline $\begin{array}{l}\text { Pre } \quad \text { construction } \\
\text { Total }\end{array}$ & 76,5 & 76,5 & 76,5 & 76,5 & 76,5 & 76,5 \\
\hline & 1081,4 & 829,3 & 469,3 & 355 & 294,6 & 209,8 \\
\hline
\end{tabular}

The ROT adjustment is performed by using the scaling factors obtained by using data in Table 4. Table 9 shows the scaling factor in NGNP 600 MWth and 350 MWth with different ROT values. Based on Table 9, it can be obtained the average scaling factor for different ROT. The average scaling factor is 0.67. By using equation 12 and the scaling 
factor, it can be obtained the overnight cost estimation of RDE and PeLUIt as shown inTable 10.

Table 9. Scaling Factor Based on ROT

\begin{tabular}{ccc|ccc}
\hline \multicolumn{3}{c|}{ 600 MWth } & \multicolumn{4}{|c}{350 MWth } \\
\hline ROT 850 & ROT 800 & $\mathrm{n}$ & ROT 850 & ROT 800 & $\mathrm{n}$ \\
764,15 & 733,34 & 0,679 & 543,4 & 520,93 & 0,697 \\
\hline ROT 850 & ROT 750 & $\mathrm{n}$ & ROT 850 & ROT 750 & $\mathrm{n}$ \\
764,15 & 704,83 & 0,646 & 543,4 & 500,14 & 0,663 \\
\hline
\end{tabular}

Table 10. Overnight cost estimation of PeLUIt

\begin{tabular}{lrrrrr}
\hline Capacity (MWth) & 350 & 100 & 50 & 30 & 10 \\
\hline $\begin{array}{l}\text { Investment cost } \\
\left(10^{6} \text { USD) }\right.\end{array}$ & 657,16 & 371,86 & 281,31 & 233,49 & 166,26 \\
\hline
\end{tabular}

It is expected that the results of RDE and PeLUIt estimation can be used as a reference in the detail design processes and economic analysis. Based on the economic analysis, it can be known that RDE and PeLUIt is economically feasible to be implemented or not.

\section{CONCLUSION}

The estimation result using scaling law is valid with error value ranges from $-30 \%$ to $+50 \%$. Based on the estimation result, we can get the overnight cost of HTGRNGNP capacity of 10 MWth up to 350MWth. By using HTGR NGNP estimation, it can be known the overnight cost of RDE and PeLUIt. RDE 10 MWth has an overnight cost 166,26 million USD. PeLUIt30 MWth has an overnight cost 233,49 million USD. PeLUIt 50 MWth has an overnight cost 281,31 million USD. PeLUIt 100 MWth has an overnight cost 371,86 million USD. PeLUIt 350 MWth has an overnight cost 657,16 million USD. The value of overnight cost can be used as one of the input data to perform economic analysis of PeLUIt implementation in Indonesia.

\section{ACKNOWLEDGEMENT}

The authors would to thank Ministry of Research and Technology (MoRT) of Indonesia for the Insinas Grant and Mr. Sriyana and Mr. Suparman for the advice to increase the quality of this research.

\section{REFERENCES}

[1] PWC, March. 2016, Private Power Utilities: The Economic Benefits of Captive Power in Industrial Estates in Indonesia, PWC Indonesia.

[2] R. Kuhr, "HTR's Role in Process Heat Applications," Nucl. Eng. Des., 2008, vol. 238, no. 11, pp. 3013-3017.

[3] C. Angulo et al., "EUROPAIRS: The European project on coupling of High Temperature Reactors with industrial processes," Nucl. Eng. Des., 2012, vol. 251, pp. 30-37.

[4] X. Yan, H. Noguchi, H. Sato, Y. Tachibana, K. Kunitomi, and R. Hino, "A hybrid HTGR system producing electricity, hydrogen and such other products as water demanded in the Middle East," Nucl. Eng. Des., vol. 271, 2014, pp. 20-29.

[5] S. Schröders, K. Verfondern, and H. J. Allelein, "Energy economic evaluation of solar and nuclear driven steam methane reforming processes," Nucl. Eng. Des., April 2017, vol. 329, no, pp. 234-246.

[6] K. Verfondern, X. Yan, T. Nishihara, and H. J. Allelein, "Safety concept of nuclear cogeneration of hydrogen and electricity," Int. J. Hydrogen Energy, 2017, vol. 42, no. 11, pp. 7551-7559.

[7] H. Sato, H. Ohashi, S. Nakagawa, Y. Tachibana, and K. Kunitomi, "Safety design consideration for HTGR coupling with hydrogen production plant," Prog. Nucl. Energy, , 2015, vol. 82, pp. 46-52.

[8] J. R. Geschwindt, L. J. Lommers, F. H. Southworth, and F. Shahrokhi, "Performance and optimization of an HTR cogeneration system," Nucl. Eng. Des, 2012, vol. 251, pp. 297-300.

[9] A. Bredimas, "Pre-economic analysis of HTR in preparation for a comprehensive economic assessment of HTRs in the world," Nucl. Eng. Des. , 2014, vol. 271, pp. 55-59.

[10] D. Hittner, E. Bogusch, M. Fütterer, S. De Groot, and J. Ruer, "High and very high temperature reactor research for multipurpose energy applications," Nucl. Eng. Des. , 2011, vol. 241, pp. 3490-3504.

[11] M. Jaszczur, M. A. Rosen, T. Sliwa, M. Dudek, and L. Pieńkowski, "Hydrogen production using high temperature nuclear reactors: Efficiency analysis of a combined cycle," Int. J. Hydrogen Energy, 2016, vol. 41, no. 19, pp. 7861-7871.

[12] X. Yan, Y. Tachibana, H. Ohashi, H. Sato, Y. Tazawa, and K. Kunitomi, "A small modular reactor design for multiple energy applications: HTR50S," Nucl. Eng. Technol. 2013, vol. 45, no. 3, pp. 401414.

[13] P. Asiedu-Boateng, E. H. K. Akaho, B. J. B. Nyarko, and S. Yamoah, "Modeling and simulation of cogeneration nuclear power plant for seawater desalination," Nucl. Eng. Des. , 2012, vol. 242, pp. 143-147.

[14] R. Reimert and M. Schad, "Process heat from modularized HTR,” Nucl. Eng. Des. 2012, vol. 251, pp. 244-251.

[15] G. Alonso, R. Ramirez, E. Del Valle, and R. Castillo, "Process heat cogeneration using a high temperature reactor," Nucl. Eng. Des. 2014, vol. 280, pp. 137-143.

[16] N. Haneklaus, E. Schnug, H. Tulsidas, and B. 
Tyobeka, "Using high temperature gas-cooled reactors for greenhouse gas reduction and energy neutral production of phosphate fertilizers," Ann. Nucl. Energy, 2015, vol. 75, pp. 275-282.

[17] C. Fang, Q. Min, Y. Yang, and Y. Sun, "Process heat applications of HTR-PM600 in Chinese petrochemical industry: Preliminary study of adaptability and economy," Ann. Nucl. Energy, 2017, vol. 110, pp. 73-78.

[18] H. Allelein and K. Verfondern, "Major milestones of HTR development in Germany and still open research issues," Ann. Nucl. Energy, 2018, vol. 116, pp. 114-127.

[19] S. Knol et al., "HTR-PM fuel pebble irradiation quali fi cation in the high $\mathrm{fl}$ ux reactor in Petten," Nucl. Eng. Des, , 2018, vol. 329, no. December 2017, pp. 82-88.

[20] W. Xu, J. Sun, Y. Zheng, and L. Shi, “The influence of nuclear graphite oxidation on air ingress accident of HTR-PM," Ann. Nucl. Energy, 2017. vol. 110 , pp. $1242-1248$

[21] J. Zhang, J. Guo, F. Li, and Y. Sun, "Research on the fuel loading patterns of the initial core in Chinese pebble-bed reactor HTR-PM," Ann. Nucl. Energy, 2018, vol. 118, pp. 235-240.

[22] Y. Inaba and T. Nishihara, "Development of fuel temperature calculation code for HTGRs," Ann. Nucl. Energy, 2017, vol. 101, pp. 383-389.

[23] Y. Fukaya, M. Goto, and T. Nishihara, "Burn-up characteristics and criticality effect of impurities in the graphite structure of a commercial-scale prismatic HTGR,” Nucl. Eng. Des, 2018, vol. 326, no. November 2017, pp. 108-113.

[24] Z. Zhang and Y. Sun, "Economic potential of modular reactor nuclear power plants based on the Chinese HTR-PM project," Nucl. Eng. Des, 2007, vol. 237, no. 23, pp. 2265-2274.
[25] Z. Zhang and S. Yu, "Future HTGR developments in China after the criticality of the HTR-10," Nucl. Eng. Des, , 2002, vol. 218, pp. 249-257.

[26] Badan Tenaga Nuklir Nasional, "Cetak Biru Pembangunan Reaktor Daya Eksperimental (RDE) 2014 - 2020," 2014

[27] INL, "Assessment of High Temperature Gas-Cooled Reactor ( HTGR ) Capital and Operating Costs," 2012.

[28] PT.PLN, JAPC, and LAPI-ITB, "Feasibility Study for Bangka Nuclear Power Plant Project-Non Site Aspect," 2013.

[29] NEA, "Current Status , Technical Feasibility and Economics of Small Nuclear Reactors," 2011.

[30] S. Oishi et al., "New scale-down methodology from commercial to lab scale to optimize plant-derived soft gel capsule formulations on a commercial scale," Int. J. Pharm., vol. 535, pp. 371378, 2018.

[31] B. Zufferey, "Scale-Down Approach: Chemical Process Optimisation Using Reaction Calorimetry for the Experimental Simulation of Industrial Reactors Dynamics,” 2006.

[32] J. Myerson, "Scaling Down: Why Designers Need to Reverse Their Thinking," J. Des. Econ. Innov., vol. 2, no. 4, pp. 288-299, 2016.

[33] AACE, "Cost Estimate Classification System - As Applied in Engineering, Procurement, and Construction for the Process Industries,” 2011. 